DOI: https://doi.org/10.24144/2409-6857.2019.2(54).71-78

УДК 628.1:338

\author{
Славік Р.В
}

\title{
РОЗВИТОК ТУРИСТИЧНО-РЕКРЕАЦЙНОЇ СФЕРИ ЗАКАРПАТСЬКОЇ ОБЛАСТІ В КОНТЕКСТІ ЗАГАЛЬНОУКРАЇНСЬКИХ ТЕНДЕНЦІЙ
}

\begin{abstract}
У даній статті досліджуються тендениії ринку рекреаційно-туристичних послуг Закарпатської області в контексті стратегічного планування розвитку рекреаційного господарства краю та його інвестиційного освоєння. Вивчаються територіальні особливості розвитку галузі в розрізі адміністративних районів Закарпатської області. Особлива увага приділена вивченню тенденцій розвитку туристичних потоків в Украӥні, місия Закарпатської області серед областей Карпатського регіону у розвитку рекреачійно-туристичної сфери, а також відвідуванню області іноземними туристами.
\end{abstract}

Ключові слова:_рекреаційно-туристична сфера, туристичні потоки, туродні, колективні засоби розміщення, санаторно-курортні і оздоровчі заклади

Постановка проблеми. Закарпатська область закономірно визнається туристичною «меккою» України в силу наявності значної кількості унікальних природних та історико-архітектурних рекреаційних ресурсів. Однак, у сучасному ринковому конкурентному середовищі наявність ресурсу $є$ тільки додатковою умовою розвитку території, але аж ніяк не достатньою. Рекреаційно-туристичне господарство Закарпатської області вимагає перманентних наукових досліджень 3 точки зору тенденцій попиту і пропозиції рекреаційних послуг та їх позиціонування на національному та міжнародному ринку, оскільки даний аналіз визначає орієнтири стратегічного планування галузі та надає важливу маркетингову інформацію потенційним інвесторам.

Аналіз останніх досліджень і публікацій. Вагомий науковий внесок у дослідження рекреаційно-туристичного господарства як галузі національної економіки та його реформування у різний час було здійснено такими вченими як Величко В.В., Гринів Л.С., Гулич О.І., Герасимчук Н.М. Копач М.В., Кузик С.П., Кравців В.С., Мацола В.І., Мальська М.П., Фоменко Н.В., Цьохла М.Ю., та ряд інших. Дослідженню рекреаційно-туристичного комплексу Закарпатської області останніми роками було присвячено ряд наукових публікацій таких дослідників як Гоблик В.В., Коваль О.Д., Кифяк В.Ф., Марченко О.I., Молнар О.С., Славік Р.В., Шандор Ф.Ф. Так, вчені Кравців В.С.,

(C) Славік Р.В., к.е.н. доц. кафедри фізичної географії та раціонального природокористування ДВНЗ «Ужгородський національний університет», Ужгород, тел. 0503726039, e-mail: ratobor_88@ukr.net
Гринів Л.С., Копач М.В. та Кузик С.П. окреслили науково-методичні засади реформування рекреаційної сфери. Гулич О.І., Гринів Л.С. та Герасимчук H.M. розробили методику формування стратегій соціально-економічного розвитку курортно-рекреаційних територій i туристичних центрів. Цьохла С.Ю. розробила стратегію економічного розвитку рекреаційної сфери. Мацола В.І. дослідив питання теорії, методології та практики рекреаційно-оздоровчотуристичного комплексу. Гринів Л.С., Славік Р.В., та Кривень О.В., дослідили теоретико-методологічні та прикладні засади економіки рекреаційної сфери у контексті сучасних вимог освіти для сталого розвитку. Дослідники Шандор Ф.Ф. та Коваль О.Д. активно досліджують питання маркетингу та менеджменту рекреаційної діяльності. На сьогодні Закарпатська область потребує перманентного комплексного аналізу тенденцій ринку рекреаційно-туристичних послуг Закарпатської області як інструментарію стратегічного планування розвитку галузі.

Формулювання цілей статті. Метою даної роботи $€$ комплексне дослідження тенденцій ринку рекреаційно-туристичних послуг Закарпатської області як передумови стратегічного планування розвитку рекреаційного господарства краю та його місце серед областей західної України з точки зору освоєності та конкурентоспроможності.

Опис основного матеріалу дослідження. За даними Всесвітньої туристичної організації ООН (ЮНВТО), частка туризму у світовому ВВП складає близько $10 \%$, а на долю міжнародного туризму припадає $6 \%$ загального обсягу світового експорту та біля $30 \%$ світового експорту послуг, кожне 11 робоче місце в світі припадає на сферу 
туризму. Прогнозується, що до 2030 року кількість міжнародних туристичних відвідувань зросте до 1,8 млрд туристів. За даними ЮНВТО у 2015 році по Європі подорожувало 609 млн туристів, їх витрати у 2014 році склали 509 млрд доларів США. Щороку спостерігається ріст міжнародних прибуттів на $5 \% \quad(1,4$ млрд. зовнішніх туристів у 2018 p), а також ріст експорту туристичних послуг на 4\% (1,7 трлн. дол. США у 2018 р.) [1]. Україна, як країна, що знаходиться в центрі Свропи має всі передумови для належного розвитку економіки за рахунок туризму. Однак, Україна суттєво програє в конкурентній боротьбі, відстаючи від провідних держав світу за рівнем розвитку туристичної інфраструктури та якості туристичних послуг.

Проаналізувавши тенденції розвитку рекреаційно-туристичної сфери України на прикладі динаміки та структури туристичних потоків починаючи з 2009 р. (рис. 1.), відмітимо, що повторюючи загальні тенденції кризових років, з 2009 р. почала помітно збільшуватися кількість українських туристів, які виїжджали за кордон разом зі стійкою тенденцією зменшення внутрішніх туристів. Дане явище може бути зумовлене, 3 одної сторони, поступовим покращенням рівня життя населення, а 3 іншої неконкурентоспроможністю口 вітчизняного рекреаційно-туристичного продукту. Анексія Криму та війна на Донбасі скорегувала всі показники турпотоків. Однак, слід відмітити, що корекція відбулася також внаслідок невідображення статистичних даних із зазначених територій в Держкомстаті. Разом 3 тим, відмітимо тенденцію до збільшення внутрішніх туристів, починаючи 2015 р., що зумовлено здебільшого, здорожченням іноземної валюти у порівнянні з гривнею. Переломним став 2018 рік. Кількість внутрішніх туристів вперше за останні 5 років скоротилася. Натомість, безпрецедентно зросла кількість туристів, громадян України, які виїжджали за кордон, досягнувши історичного максимуму з 2000 року. Це зумовлено, в першу чергу, запровадженням безвізового режиму з Європейським Союзом, а також загальним покращенням соціальноекономічного стану в державі.

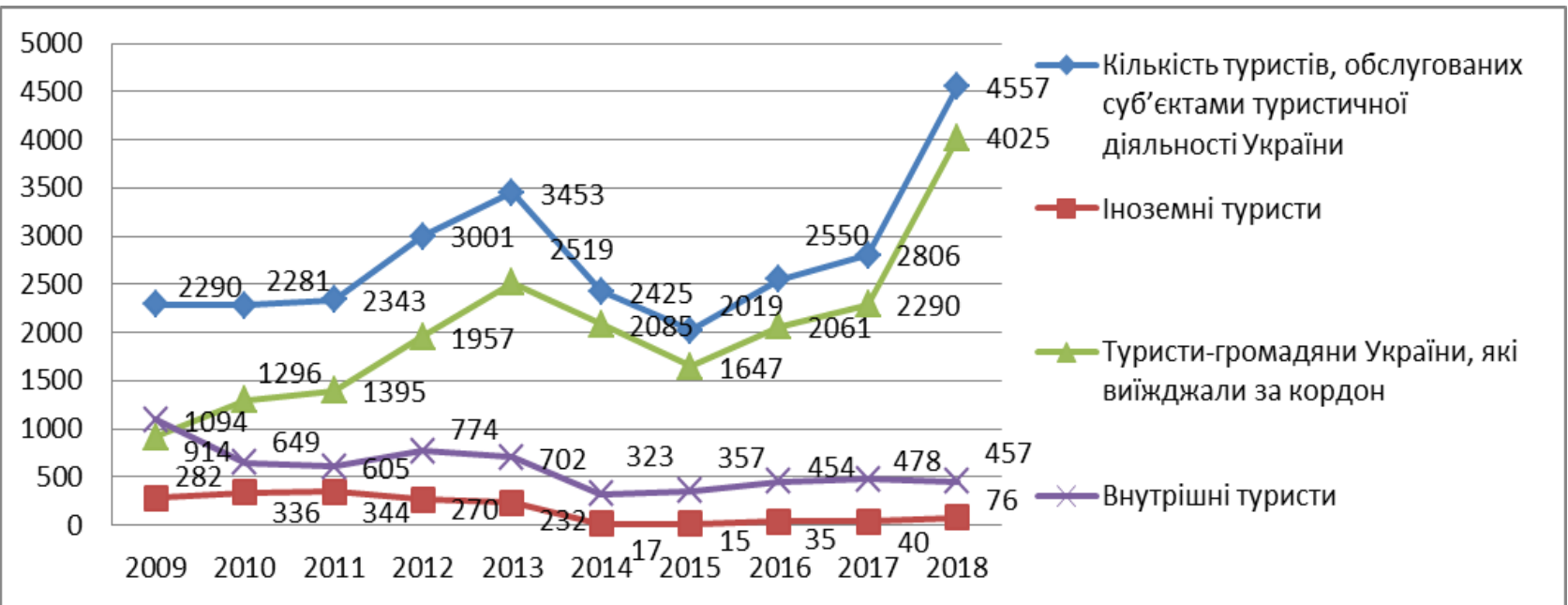

*складено на основі даних [2]

Рис. 1. Туристичні потоки в Україні, 2009-2018 рр., тис. осіб*

Зменшення попиту на вітчизняний рекреаційно-туристичний продукт, в першу чергу, негативно впливає на розвиток традиційних рекреаційних регіонів України Карпатського, Причорноморського, Поліського тощо. У зв'язку 3 цим, виникає об'єктивна необхідність більш ефективних дій державного менеджменту в контексті позиціонування національного рекреаційного продукту на ринку, сприяння залучення інвестицій у галузь, покращення стану інфраструктури тощо.

Незважаючи на кризові економічні процеси в українській економіці, падіння курсу гривні дає вагомі економічні передумови для в’їного туризму, що має стати своєрідним каталізатором розвитку рекреаційно-туристичної сфери загалом. В даному контексті, Стратегія розвитку туризму та курортів до 2026 року конкретизовує стратегічні орієнтири та завдання розвитку рекреаційної сфери України та є орієнтиром для розробки відповідних регіональних програм, особливо у рекреаційно орієнтованих регіонах: Карпатському, Причорноморському, Поліському тощо [3].

Динамічному розвитку ринку рекреаційнотуристичних послуг в Україні сприяє зокрема, світова кон'юнктура, переорієнтація напрямків потоків туристів та зміна філософії подорожей. 
Так, згідно щорічних звітів ВТО [1], збільшується попит на нові, недостатньо вивчені напрямки, на противагу традиційним. Кількість подорожей до розвинутих країн та країн, що розвиваються, поступово вирівнюється i у 2012 p. співвідношення склало 550 до 485 млн. (у 1995 р. - 337 до 193 млн.). Серед регіонів світу, інтерес до яких постійно зростає - Південна і Південносхідна Азія. У Свропі найбільшими темпами зростає кількість подорожей та доходи від туризму у Південній, Центральній та Східній Європі. Такому стану справ сприяє також занепад традиційних напрямків до Північної Африки та
Близького Сходу внаслідок політичних подій останніх років. Таким чином, однією 3 цілей стратегічного планування розвитку рекреаційної сфери має бути залучення вивільнених потоків подорожуючих саме в Україну.

Об'єктивну картину стану рекреаційної сфери можна отримати, прослідкувавши закономірності розвитку санаторно-курортної та оздоровчої сфер, тенденцій туристичних потоків у державі та розвиток готельного господарства 3 іншими закладами розміщення. На рис. 2 показані тенденції розвитку санаторно-курортної сфери України за останні роки.

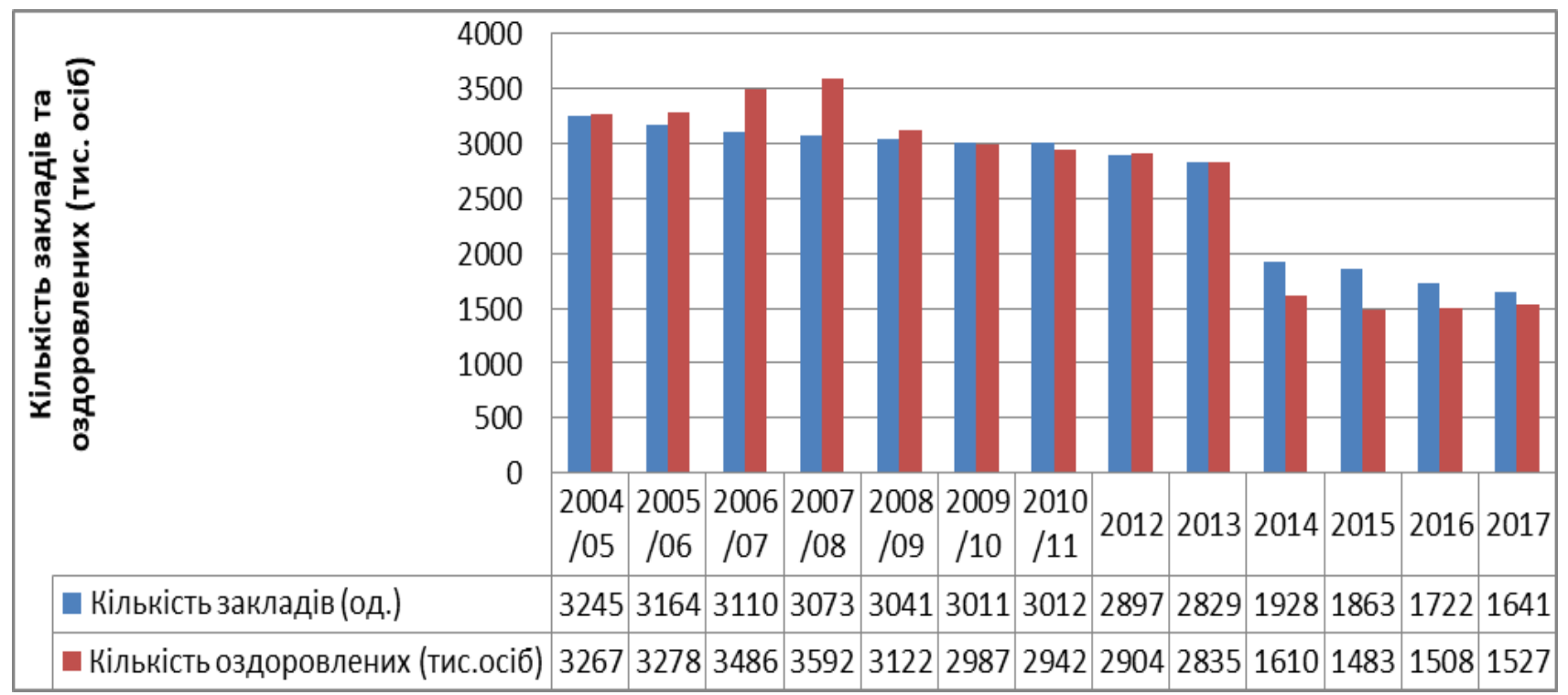

Рис. 2. Санаторно-курортні і оздоровчі заклади України [4]

Як видно 3 даних рис. 2, стан санаторнокурортної і оздоровчої сфери в Україні до 2014 р. можна класифікувати як застійний з ознаками стагнації. За період, що досліджувався, чисельність санаторно-курортних і оздоровчих закладів перманентно зменшувалася, що пояснюється, зокрема, зміною їх функціонального призначення, оптимізацією діяльності та реструктуризацією профспілкових санаторіїв. Щодо кількості оздоровлених осіб у згаданих закладах, то відмітимо незначне зростання їх чисельності до кризового 2008 р., після чого спостерігалася низхідна тенденція, особливо у 2014-2017 рр., коли припинився облік санаторно-курортних закладів в АР Крим та частині Донбасу.

Загальноукраїнські тенденції кореляційно відображаються i на стані рекреаційнотуристичної сфери Закарпатської області. Володіючи унікальними природними та історикоархітектуриними ресурсами, область не до кінця реалізовує свій потенціал з ряду причин, а саме:
- $\quad$ важка доступність області для комунікації 3 рештою України за допомогою різних видів транспорту (залізничного, авіаційного);

- $\quad$ конкуренція сусідніх областей та країн;

- недостатній розвиток автодорожньої інфраструктури;

- $\quad$ периферійне положення в Україні;

- недостатне позиціонування та брендинг Закарпаття як туристичного напрямку в Україні і за кордоном.

Не зважаючи на перераховані перешкоди розвитку рекреаційно-туристичного сектору, Закарпатська область зуміла вийти на довоєнний рівень, i навіть перевершити показники відвідуваності туристично-рекреаційних закладів 2013 року (342,2 тис. осіб). Статистичні дані динаміки відвідувачів туристично-рекреаційних закладів Закарпатської області оперативного моніторингу відділу туризму та курортів Закарпатської ОДА показані у табл. 1.

Як видно 3 таблиці, спостерігається висхідна тенденція відвідувачів туристично-рекреаційних закладів у Закарпатській області, що пов'язано із 
закінченням активної фази бойових дій на сході у 2014-15 pp. У 2016 році зафіксовано пікову відвідуваність туристично-рекреаційних закладів через різке зростання даного показника у Іршавському, Рахівському, Міжгірському,

Динаміка відвідувачів туристично-рекреаційних закладів по районах Закарпатської області,

\begin{tabular}{|c|c|c|c|c|c|c|c|c|c|}
\hline \multicolumn{10}{|c|}{ ociб [5] } \\
\hline Території & 2014 & 2015 & 2016 & 2017 & 2018 & $\begin{array}{c}2016 / \\
2015, \\
\%\end{array}$ & $\begin{array}{c}2017 / \\
2016, \\
\%\end{array}$ & $\begin{array}{c}2018 / \\
2017 \\
\%\end{array}$ & $\begin{array}{c}2018 / \\
2014 \\
\%\end{array}$ \\
\hline Берегівський & 85293 & 95663 & 88147 & 73941 & 95564 & 92,1 & 83,9 & 129 & 112 \\
\hline Вел.Березнянський & 0 & 3356 & 3149 & 5755 & 3532 & 93,8 & 183 & 61,4 & - \\
\hline Виноградівський & 2268 & 2329 & 3496 & 2038 & 1329 & 150 & 58,3 & 65,2 & 58,6 \\
\hline Воловецький & 3327 & 3042 & 3067 & 3728 & 2636 & 100,8 & 121,6 & 70,7 & 79,2 \\
\hline Іршавський & 2118 & 1610 & 4196 & 6730 & 4368 & 260,6 & 160,4 & 64,9 & 206,2 \\
\hline Міжгірський & 13771 & 14073 & 18730 & 25273 & 20717 & 133 & 134,9 & 82 & 150 \\
\hline Мукачівський & 26677 & 24930 & 29306 & 32871 & 39350 & 117,6 & 112,2 & 119,7 & 147,5 \\
\hline Перечинський & 4739 & 6069 & 8439 & 5528 & 4883 & 139 & 65,5 & 88,3 & 103 \\
\hline Рахівський & 26550 & 22047 & 32348 & 24341 & 32627 & 146,7 & 75,2 & 134 & 122,9 \\
\hline Сваля & 25229 & 35841 & 61635 & 19570 & 23972 & 172 & 31,8 & 122,5 & 95 \\
\hline Тячівський & 32595 & 26470 & 34112 & 25715 & 31402 & 128,9 & 75,3 & 122 & 96,3 \\
\hline Ужгородський & 9955 & 8452 & 10444 & 19589 & 25119 & 123,6 & 187,6 & 128,2 & 252,3 \\
\hline Хустський & 63478 & 51331 & 50704 & 44444 & 39016 & 98,8 & 87,7 & 87,8 & 61,5 \\
\hline м. Ужгород & 22532 & 10715 & 2127 & 208 & 0 & 19,9 & 110 & 9,8 & - \\
\hline м.Мукачево & 8753 & 8632 & 24627 & 25497 & 19940 & 285,3 & 103,5 & 78,2 & 227,8 \\
\hline M.Хуст & 5433 & 7792 & 8434 & 8277 & 8753 & 108,2 & 98,1 & 105,8 & 161,1 \\
\hline м.Берегово & 5817 & 5439 & 9723 & 13260 & 10335 & 178,8 & 136,4 & 77,9 & 177,7 \\
\hline Разом & \begin{tabular}{|l}
338535 \\
\end{tabular} & 327791 & 392684 & 336765 & 363543 & 119,8 & 85,8 & 108 & 107,4 \\
\hline
\end{tabular}

Свалявському районах та містах Мукачево та Берегово. Ці ж райони, а також Ужгородський i місто Хуст стали основними драйверами збільшення туристичних потоків у Закарпаття. Серед основних причин можна виділити:

- інтенсифікація освоєння ресурсів термальних вод у м. Берегові та Берегівському районі, а також інфраструктурна розбудова діючих термальних комплексів. Також, позиціонування району як центру сільського зеленого та етнотуризму у селах Бене, Мужієво, Четфалва, Гече та ін..;

- позиціонування Закарпаття як «Землі, наближеної до неба», що сприяє розвитку екологічного туризму у високогірних Рахівському та Міжгірському районах на базі Карпатського біосферного заповідника та НПП «Синевір»;

- інфраструктурна розбудова історичних центрів міст внаслідок децентралізації бюджетів;

- створення об’єднаних територіальних громад у зазначених районах, що $є$ стимулом створення нових господарюючих суб'єктів, зокрема, закладів розміщення, а також легалізації існуючих (Баранинська, Іршавська, Полянська ОТГ та ін.);

- $\quad$ розбудова автодорожньої інфраструктури до основних туристичних напрямків області (с.
Лумшори, оз. Синевір, с. Колочава, м. Хуст тощо.).

Стагнаційні тенденції спостерігаються у Виноградівському, Воловецькому та Хустському районах. Однак причини цьому різні. Виноградівський район більше позиціонується як напрямок одноденного відвідування туристів (буйволина ферма в с. Олешник, плантація цитрусових, історичний центр міста Виноградів 3 руїнами замку Канків, винні дегустації тощо) без тривалого розміщення на території району. Щодо Воловецького району, то не зважаючи на певну розбудову туристичної інфраструктури у селах Жденієво, Верхня Грабівниця, Гукливий, район залишається переважно транзитним. Певне зменшення туристичних потоків у Хустському районі зумовлено бурхливим розвитком туристичної інфраструктури у 2013-2016 рр. та появою конкуренції зі сторони сусідніх районів.

Попри певне перевищення показника відвідуваності туристів Закарпатської області в порівнянні 3 довоєнним періодом, показник кількості туроднів, проведених останніми в Закарпатті, відновлюється повільно тільки з 2018 року. Дане явище пов'язано зі зменшенням тривалості турів у область. Популярними є дво або триденні тури вихідного дня. У зв'язку зі зменшенням кількості туроднів, проведених туристами у Закарпатській області, спостерігається збалансування попиту i 
пропозиції на послуги розміщування. Так, за період з 2014 по 2017 роки стабільно знижувалася як кількість колективних засобів розміщування (3 287 одиниць до 250 відповідно) так і кількість місць у них (з 17929 до 15310 відповідно). При цьому, низхідні тенденції стосуються як готелів та аналогічних засобів розміщування, так i спеціалізованих засобів. Натомість, обсяг наданих туристично-рекреаційних послуг перевищив довоєнний показник більш, ніж вдвічі, що пояснюється, переважно, інфляційними процесами та знеціненням національної валюти (рис. 3).

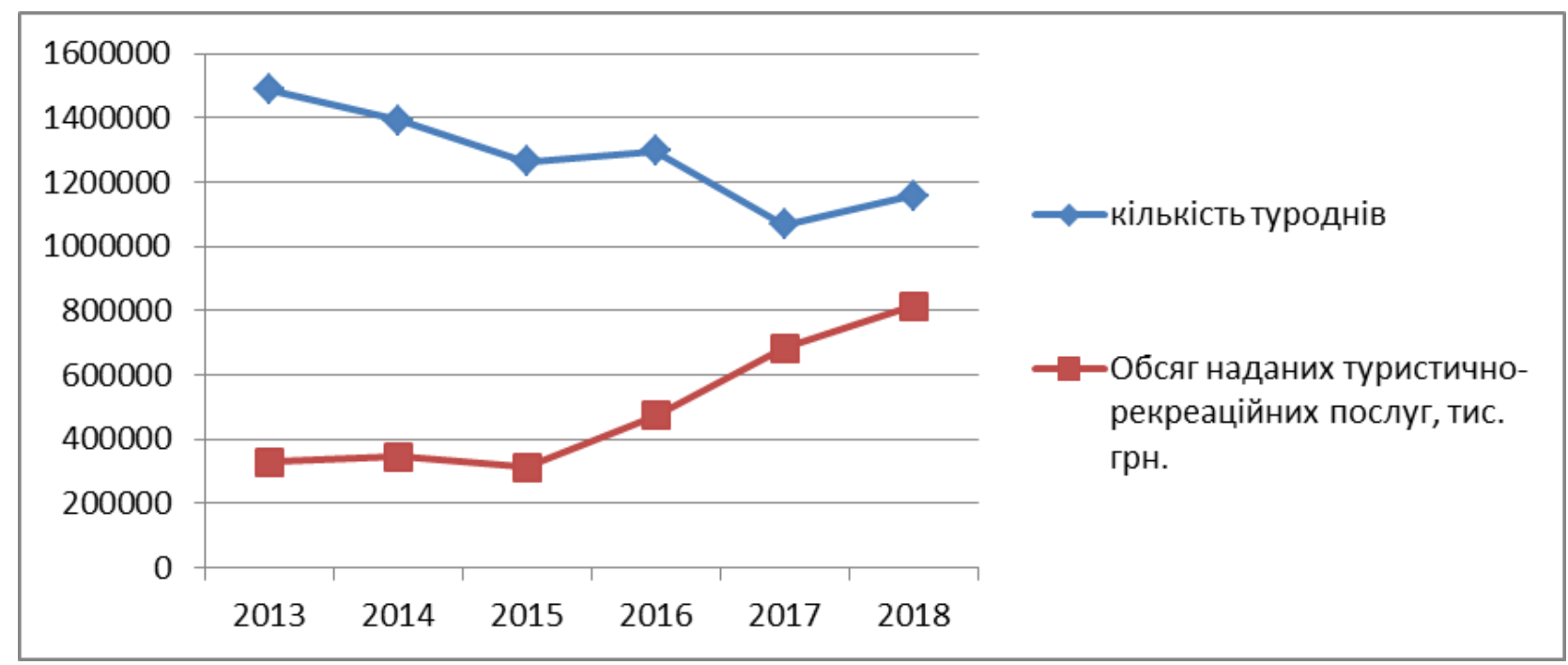

Рис. 3. Кількість туроднів, проведених туристами у Закарпатській області та обсяг наданих туристично-рекреаційних послуг, тис. грн. [5]

Розвиток рекреаційно-туристичної сфер Закарпатської області необхідно розглядати в контексті інших областей Карпатського регіону, оскільки, вони, 3 однієї сторони ділять туристичний напрямок «Українські Карпати», 3 іншої - виступають конкурентами. Туристичні потоки, а відповідно і місця у колективних засобах розміщення розділені нерівномірно. Беззаперечним лідером Карпатського регіону $є$ Львівська область, яка лідирує за обома показниками, що може пояснюватися туристичною привабливістю міста Львова (Рис. $4,5)$.

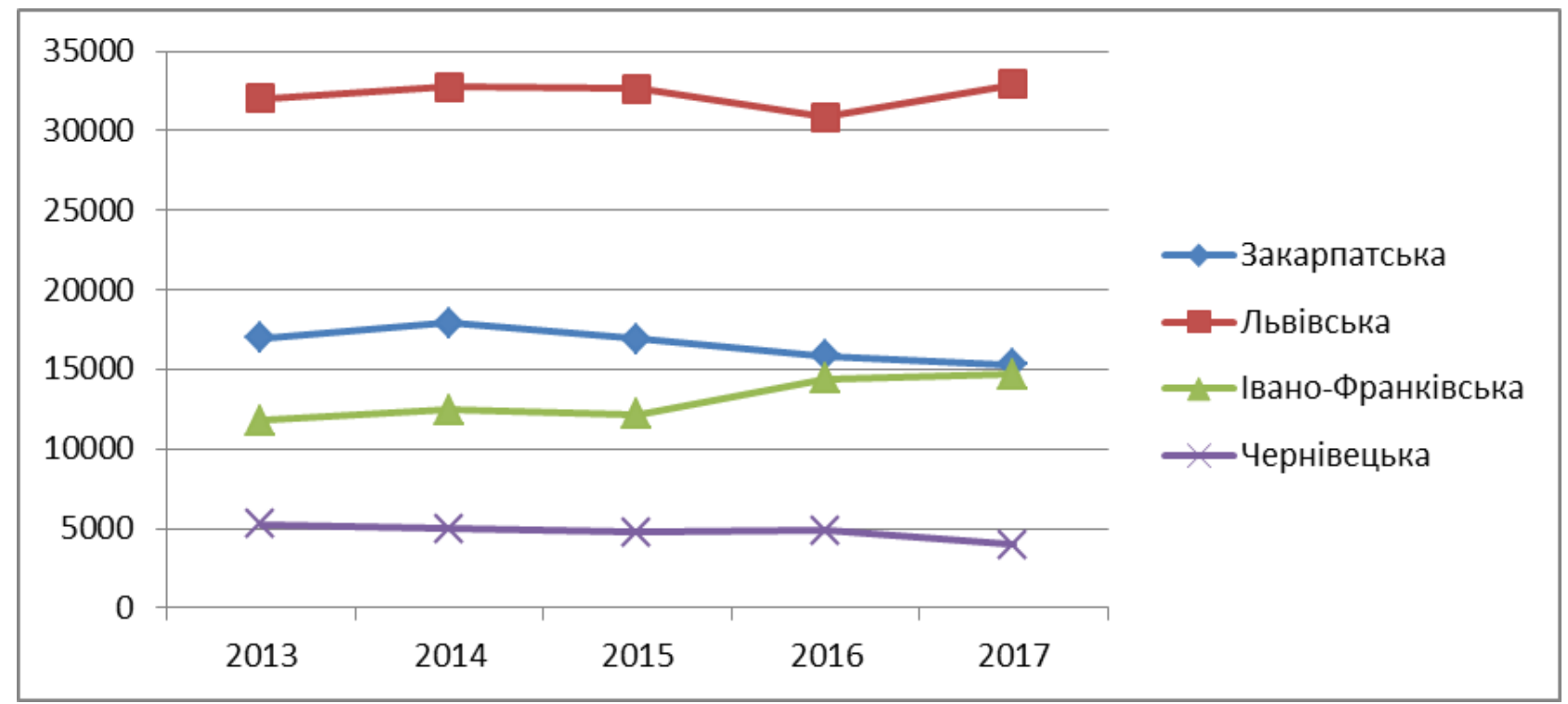

Рис. 4. Кількість місць у колективних засобах розміщення за областями Карпатського регіону, од (2013 - 2017 рp.) [6,7,8,9]

Закарпатська область, наразі, друга у регіоні за кількістю місць у колективних засобах розміщення, однак, тенденція низхідна. За даним показником ii наздоганяе Івано-Франківська область, оскільки показник кількості осіб, що перебували у колективних засобах розміщення, $\epsilon$ 
вищим і тенденція йде до збільшення. Таким чином, існує потреба у розбудові туристичної інфраструктури. Найнижчі згадані показники у Чернівецькій області, що може бути пов'язано з їі найменшими розмірами як за населенням так і за площею, а також розташуванням найменшого сектору Українських Карпат на їі території.

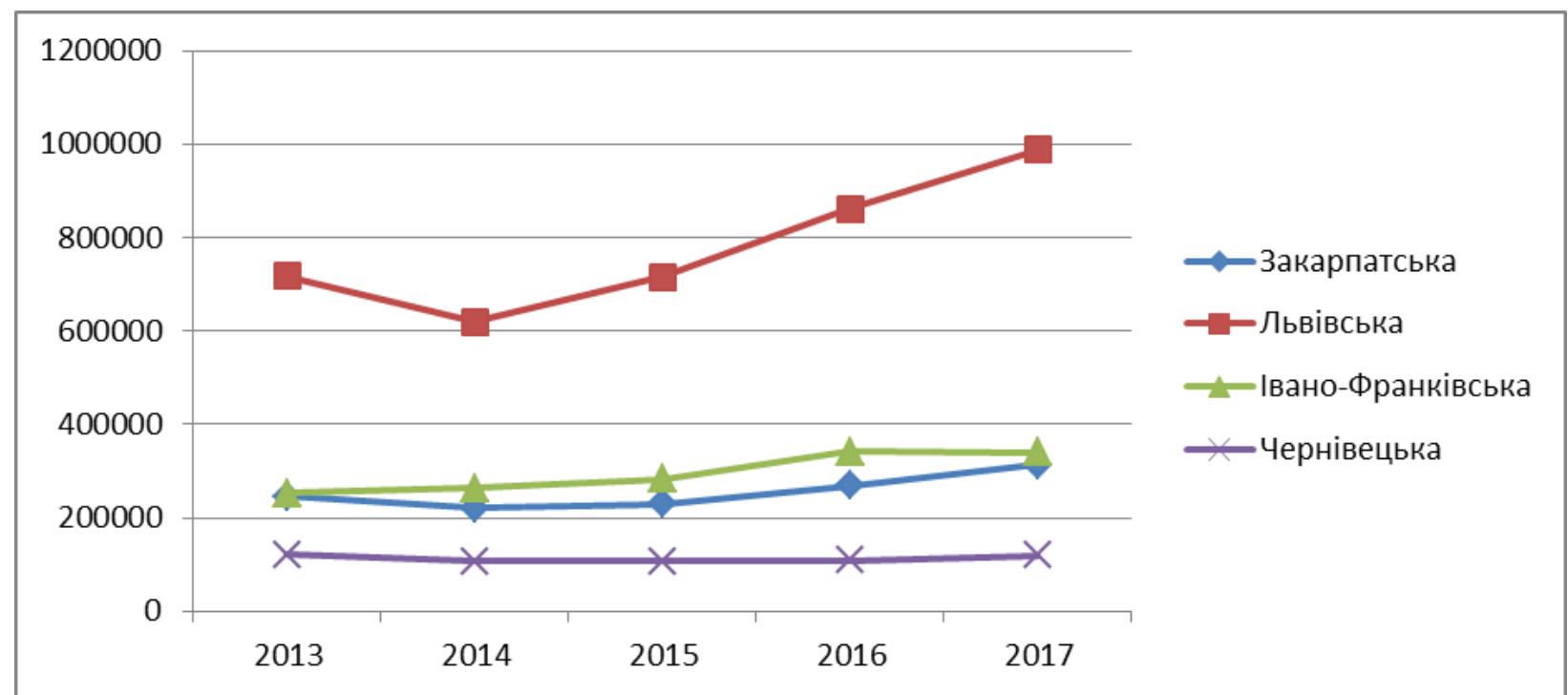

Рис. 5. Кількість осіб, що перебували у колективних засобах розміщення за областями Карпатського регіону у $2013-2017$ pp. [6,7,8,9]

Важливим показником розвитку рекреаційнотуристичної сфери $є$ відвідуваність певної території іноземними туристами. Останні в свою чергу сприяють притоку іноземної валюти в державу i, загалом, укріпляють національну валюту. 3 іншої сторони, міжнародний туризм відіграє важливу соціальну функцію міжнародного спілкування та культурного обміну. Однак відвідуваність певної території саме іноземними туристами вимагає створення відповідного рівня сервісу та врахування національних особливостей країн, звідки прибувають туристи, при створенні туристичного

\section{1 рік}

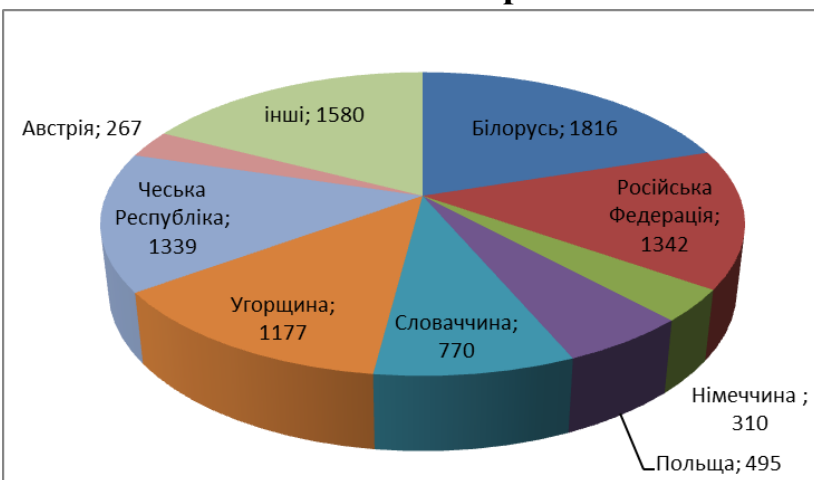

продукту. Аналізуючи загальноукраїнську тенденцію в'їзного туризму, відмітимо майже двократне збільшення іноземних туристів, які були обслужені українськими турагентами i туроператорами. Однак, слід зауважити низьку базу порівняння у минулі роки. Згідно офіційних даних Головного управління статистики у Закарпатській області, у 2018 році в колективних засобах розміщення перебувало 10021 іноземець. Порівняльна характеристика розподілу іноземних туристів за країнами у 2011 і 2018 роках виглядає наступним чином (рис. 6.).

\section{8 рік}

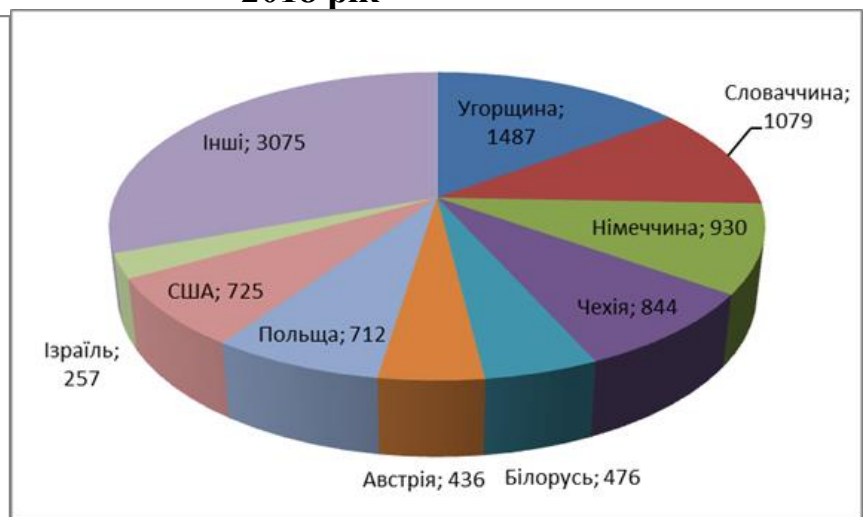

Рис. 6. Розподіл іноземців, що перебували в колективних засобах розміщування за країнами, з яких вони прибули у 2011 та 2018 роках [2]

За абсолютною кількістю іноземних туристів, вдалося вийти на довоєнний рівень, однак змінилася структура туристів за країнами походження. Так, майже повністю припинилося відвідування області туристами 3 Російської Федерації. Найбільша кількість туристів спостерігається 3 сусідніх країн - Угорщини, Словаччини та Польщі. Якщо угорський турист відвідував Закарпаття через традиційні родинні зв'язки, а також значну пов'язаність 3 угорською 
історією, то кількість словацьких та польських туристів збільшується через дорожчання туристичних послуг у країнах центральної Європи, а також покращення туристичного сервісу в Україні загалом і західних областях зокрема. 3 початком війни на Донбасі радикально зменшилася кількість туристів з Білорусі, однак, на відміну від російських туристів їх кількість 3 кожним роком зростає. Традиційно висока відвідуваність Закарпаття чеськими туристами. Значно зросла кількість туристів із західної Європи, особливо 3 Німеччини і Австрії. Тенденцією останніх років є також поява значної кількості туристів зі США та Ізраїлю, що пов'язано 3 розвитком, так званого, ностальгічного туризму, або відвідування місць проживання своїх предків, які емігрували до Другої світової війни, або під час існування Радянського Союзу. Підсумовуючи, відмітимо, що значно диверсифікувалася кількість, країн, 3 яких прибувають туристи в закарпатську область разом зі скороченням останніх із країн східної Європи.

Висновки i перспективи подалыших досліджень. Аналізуючи динаміку відвідування туристично-рекреаційних закладів Закарпатської області, відзначимо, що область за даним показником повернулася на довоєнний рівень 2012-2013 років після значного падіння 2014 року. Незважаючи на падіння внутрішнього туризму в Україні у 2018 році, Закарпатській області вдається стабільно збільшувати кількість відвідуючих. Основними драйверами росту $\epsilon$ Берегівський, Рахівський, Мукачівський, Ужгородський i Міжгірський райони. Щодо рекреаційної сфери України, відмітимо, що незважаючи на стабільне зменшення кількості санаторно-курортних та оздоровчих закладів, кількість оздоровлених осіб у них зростає протягом останніх років, що свідчить про оптимізацію їх діяльності. Протягом останніх років популярними стали дво і триденні тури, особливо серед іноземних туристів. Серед областей Карпатського регіону, Закарпатська область незначно поступається ІваноФранківській за пропозицією послуг розміщення, однак впевнено наздоганяє за попитом на останні. Щодо відвідування Закарпатської області іноземними туристами, то за останні роки різко скоротилась кількість останніх 3 країн СНД, разом зі збільшенням їх кількості i диверсифікацією з країн західної Європи, США та Ізраїлю.

3 огляду на висхідні тенденції, які склалися на ринку рекреаційно-туристичних послуг Закарпатської області, виникає об'єктивна необхідність розробки комплексної стратегії розвитку рекреаційного господарства краю, яка б сприяла посиленню інвестиційних процесів у галузі та зберегла позитивні тенденції розвитку.

\section{ПЕРЕЛІК ВИКОРИСТАНИХ ДЖЕРЕЛ}

1. Міжнародна туристична організація: URL: http://www2.unwto.org/press-release/2019-0829/tourism-enjoys-continued-growth-generating-usd-5-billion-day

2. Головне управління статистики у Закарпатській області. «Закарпаття - санаторії та туризм. Статистичний збірник». Ужгород: 2019 р.

3. Стратегія розвитку туризму та курортів на період до 2026 року. - розпорядження КМУ від 16 березня 2017 p. № 168-p: URL: https://www.kmu.gov.ua/ua/npas/249826501

4. Державна служба статистики України. «Україна у цифрах 2017». Статистичний збірник. К.: 2018 p.

5. Дані оперативного моніторингу відділу туризму та курортів Закарпатської ОДА за 2018 рік.

6. Головне управління статистики у Закарпатській області: URL: http://uz.ukrstat.gov.ua/statinfo/turism/index.html

7. Головне управління статистики у Івано-Франківській області: URL: http://www.ifstat.gov.ua/
8. Головне
управління
статистики
у Львівській області:
URL:

https://www.lv.ukrstat.gov.ua/ukr/si/inf_2009.php?vid=1\&code=24\&show=1\&show1=1

9. Головне управління статистики у Чернівецькій області: URL: http://www.cv.ukrstat.gov.ua/

10.Гринів Л.С., Славік Р.В., Кривень О.В. Економіка рекреаційної сфери: навч. посібник. Львів: ЛНУ імені Івана Франка, 2019. - 416 с.

11.Гулич О. І., Гринів Л. С., Герасимчук Н. М. Методика формування стратегій сталого соціальноекономічного розвитку курортно-рекреаційних територій і курортних центрів. НАН України, IPД ЛЬВІВ. 2007. $-52 \mathrm{c}$.

12.Долішній М.І., Нудельман М.С., Ткаченко К.К. та ін. Карпатський рекреаційний комплекс. Академія наук УРСР. Львівське відділення Інституту економіки. Київ: Наукова думка, 1984. - 147 с.

13.Кравців В.С., Гринів Л.С., Копач М.В., Кузик С.П. Науково-методичні засади реформування рекреаційної сфери Наукове видання. Львів: НАН України. - ІРД НАН України. - 1999. - 78 с. 
14.Мацола В.І. Рекреаційно-оздоровчо-туристичний комплекс (питання теорії, методології, практики): Монографія (Інститут регіональних досліджень НАН України. Редкол.: М.І. Долішній (відп. редактор). Львів, 1998. - 278 с.

15.Молнар О.С., Марченко О.I. Оцінка наявного туристично-рекреаційного потенціалу рекреаційних зон Закарпаття: URL: http://www.transcarpathiatour.com.ua/publications/statia2_ind.html

\section{REFERENCES}

1. Mizhnarodna turystychna organizaciya [World Tourism Organization]. Retrieved from: http://www2.unwto.org/press-release/2019-08-29/tourism-enjoys-continued-growth-generating-usd-5billion-day [in English].

2. Golovne upravlinnya statystyky u Zakarpatskij oblasti / «Zakarpattya - sanatoriyi ta turyzm. Statystychnyj zbirnyk» [Main Department of Statistics in the Transcarpathian region / «Transcarpathia sanatoriums and tourism. Statistical Collection »] / Uzhgorod: 2019.

3. Strategiya rozvytku turyzmu ta kurortiv na period do 2026 roku. - rozporyadzhennya KMU vid 16 bereznya 2017 r. [Tourism and Resort Development Strategy for 2026. - CMU's order dated March 16, 2017] № 168-p. Retrieved from: https://www.kmu.gov.ua/ua/npas/249826501 [in Ukrainian]

4. Derzhavna sluzhba statystyky Ukrayiny / «Ukrayina u cyfrax 2017». Statystychnyj zbirnyk [State Statistics Service of Ukraine / Ukraine in Figures 2017. Statistical collection]. Kyiv: 2018.

5. Dani operatyvnogo monitoryngu viddilu turyzmu ta kurortiv Zakarpatskoyi ODA za 2018 rik [Data of operational monitoring of the Department of Tourism and Resorts of Transcarpathian Regional State Administration for 2018].

6. Golovne upravlinnya statystyky u Zakarpatskij oblasti [Main Department of Statistics in the Transcarpathian region]. Retrieved from: http://uz.ukrstat.gov.ua/statinfo/turism/index.html [in Ukrainian].

7. Golovne upravlinnya statystyky u Ivano-Frankivskiy oblasti [Main Department of Statistics in the Ivano-Frankivsk region]. Retrieved from: http://www.ifstat.gov.ua/ [in Ukrainian].

8. Golovne upravlinnya statystyky u Lvivskiy oblasti [Main Department of Statistics in the Lviv region]. Retrieved from: https://www.lv.ukrstat.gov.ua/ukr/si/inf_2009.php?vid=1\&code=24\&show=1\&show1=1 [in Ukrainian].

9. Golovne upravlinnya statystyky u Cherniveckiy oblasti [Main Department of Statistics in the Chernivci region]. Retrieved from: http://www.cv.ukrstat.gov.ua/ [in Ukrainian].

10. Gryniv L.S., Slavik R.V., Kryven O.V. Ekonomika rekreacijnoyi sfery: navch. posibnyk. Lviv: LNU imeni Ivana Franka [Recreational Economics: Educ. manual. Lviv: Ivan Franko National University]: 2019. $416 \mathrm{p}$.

11.Gulych O. I., Gryniv L. S., Gerasymchuk N. M. Metodyka formuvannya strategij stalogo socialnoekonomichnogo rozvytku kurortno-rekreacijnyx terytorij i kurortnyx centriv. NAN Ukrayiny, IRD [Methods of formation of strategies for sustainable socio-economic development of resort and recreation areas and resort centers. NAS of Ukraine, IRD]. LVIV: 2007. - 52 p.

12. Dolishnij M.I., Nudelman M.S., Tkachenko K.K. ta in. Karpatskyj rekreacijnyj kompleks. Akademiya nauk URSR. Lvivske viddilennya Instytutu ekonomiky. Kyiv: Naukova dumka [Carpathian recreational complex. USSR Academy of Sciences. Lviv Branch of the Institute of Economics. Kiev: Scientific Opinion]: 1984. $-147 \mathrm{p}$.

13.Kravciv B.C., Gryniv L.S., Kopach M.V., Kuzyk S.P. Naukovo-metodychni zasady reformuvannya rekreacijnoyi sfery Naukove vydannya. Lviv: NAN Ukrayiny. - IRD NAN Ukrayiny [Scientific and methodological bases of recreational sphere reforming. Scientific publication. Lviv: NAS of Ukraine. - IRD NAS of Ukraine]: $1999 .-78 \mathrm{p}$.

14.Maczola V.I. Rekreacijno-ozdorovcho-turystychnyj kompleks (pytannya teoriyi, metodologiyi, praktyky): Monografiya (Instytut regionalnyx doslidzhen NAN Ukrayiny. Redkol.: M.I. Dolishnij (vidp. redaktor) [Recreational-health-tourist complex (issues of theory, methodology, practice): Monograph (Institute for Regional Studies of NAS of Ukraine. Ed.: MI Dolishniy (editor-in-chief)] Lviv: 1998. - 278 p.

15. Molnar O.S., Marchenko O.I. Ocinka nayavnogo turystychno-rekreacijnogo potencialu rekreacijnyx zon Zakarpattya [Assessment of the existing tourist and recreational potential of the recreation zones of Transcarpathia]. Retrieved from: http://www.transcarpathiatour.com.ua/publications/statia2_ind.html [in Ukrainian]. 